\begin{tabular}{|c|c|c|}
\hline 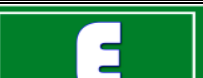 & International Journal of Current Research in & \\
\hline & Biosciences and Plant Biology & \\
\hline $\begin{array}{l}\text { EXCELLENT } \\
\text { PUBLISHERS } \\
\end{array}$ & $\begin{array}{c}\text { ISSN: 2349-8080 (Online) } \bullet \text { Volume } 3 \bullet \text { Number } 9 \text { (September-2016) } \\
\text { Journal homepage: } w \text { ww.ijcrbp.com }\end{array}$ & \\
\hline
\end{tabular}

\title{
Nutritional-Reproductive Efficiency Relationship of European Sea Bass, Dicentrarchus labrax (Linnaeus, 1758) Brood Stock: Condition Factor, Organs Indices, Anatomical and Histological Characteristics
}

\author{
Eman H. Maklad, Ahmed I. Mehrim* and Mohamed Z.A. Mohamed \\ Animal Production Department, Faculty of Agriculture, Mansoura University, Al-Mansoura, PC. 35516, Egypt \\ *Corresponding author.
}

\section{A b s t r a c t}

A feeding trial was conducted to study the effect of the live (trash fish) food $\left(\mathrm{T}_{1}\right)$, artificial diet $\left(\mathrm{T}_{3}\right)$ or mixed between them $\left(\mathrm{T}_{2}\right)$ at rate $(1: 1)$ on condition factor $\left(\mathrm{K}_{\mathrm{f}}\right)$, gonado somatic index (GSI) and hepato somatic index (HSI) parameters, besides the anatomical and histological alterations of the gonads and the liver of Dicentrarchus labrax females and males brood stock through the feed period at 45 days, then spawning period at 15 days. In the feeding period, a total of 180 Sea bass brood stock females and males were used. The 90 females with $1190-1820 \mathrm{~g}$ per fish as an initial body weight were separately allotted in 9 concert tanks (three tanks / treatment). Also, 90 males with initial body weight ranged between $(880-1400 \mathrm{~g}$ per fish) separately allotted in other 9 concert tanks. Fish were stocked at 10 fish per concrete tank $(8 \times 4 \times$ $1 \mathrm{~m}$ ) in black greenhouse in the same experimental conditions. The obtained results revealed that both sex fed the artificial diet $\left(\mathrm{T}_{3}\right)$ significantly increased the $\mathrm{K}_{\mathrm{f}}$, GSI, and HSI compared to other dietary treatments $\left(\mathrm{T}_{1}\right.$ and $\left.\mathrm{T}_{2}\right)$. Also, the same treatment $\left(\mathrm{T}_{3}\right)$ seriously improved in the anatomical and histological of the gonads and the liver among other dietary treatments. The feeding fish on artificial diet $\left(\mathrm{T}_{3}\right)$ had more effective on all tested parameters compared to the trash fish or the mixed diets, particularly for of females than males. Thus from the current findings, it could be concluded that the useful using of the good quality artificial diet in D. labrax hatcheries for enhancement their reproductive efficiency. Also these findings confirmed on the positively relationship between the feeding sources and reproductive efficiency of $D$. labrax brood stock, especially for females.
\end{abstract}

\section{Article Info}

Accepted: 26 August 2016

Available Online: 06 September 2016

Keywords

Anatomy

Feeding

Gonads

Histology

Sea bass

\section{Introduction}

European Sea bass, Dicentrarchus labrax is the most important commercial and consumed marine fish. At present it is the widely cultured in the Mediterranean area, with Greece, Turkey, Italy, Spain, Croatia, and Egypt being the largest producers (FAO, 2012). European Sea bass is a seasonal breeder, spawning in winter and early spring, with some differences in timing according to the specific location. There is only one reproductive season per year, which takes place in winter in the Mediterranean population (December to March) and up to June in the Atlantic populations (Moretti et al., 1999).

Fish nutrition is a matter of great importance in the expanding Mediterranean aquaculture industry as better product quality and optimum growth can be achieved using the appropriate diets (Parpoura and Alexis, 2001). The main objective when formulating a fish diet is to 
provide a nutritionally balanced mixture of ingredients to support the maintenance, growth, reproduction and health of the animal at an affordable cost (NRC, 1993). As feed is one of the principle costs in feed production (Lupatsch et al., 2001), formulations must be based on our knowledge of nutritional requirements for them to be economically viable.

Reproduction in fish, as in other vertebrates, is affected by environmental, social and nutritional factors. The effects of food ration size and nutrient composition of the diets on reproduction have been investigated in several species important in aquaculture (Kjørsvik et al., 1990; Bromage et al., 1992). The quality and quantity of food are among the most important exogenous factors directly affecting growth and, indirectly, maturation and mortality in fish, thus being ultimately related to fitness (Wootton, 1990). However, the effect of the sources of fish feeds on the reproductive efficiency of marine fish, partially $D$. labrax brood stock is requiring further investigations. Therefore, the present study was designed to investigate the effects of the live, artificial food or mixed between them at rate $(1: 1)$ on condition factor $\left(\mathrm{K}_{\mathrm{f}}\right)$, organs indices parameters, besides the anatomical and histological alterations of the gonads and the liver of D. labrax males and females brood stock.

\section{Materials and methods}

The present study was performed in El-Sherif private marine fish farm, Wady Mariot, Alexandria Governorate, Egypt. It was conducted into two periods, the first period is a feeding period for 45 days, then the maturation brood stock females injected with 1000 IU hCG (from Argent ${ }^{\circledR}$, US A)/Kg body weight according to Moretti et al. (1999) before the second period as a spawning period for 15 days.

\section{Experimental procedures}

European Sea bass D. labrax males and females brood stock were obtained from El-Sherif private marine fish farm, Wady Mariot, Alexandria Governorate, Egypt. Females and males were carefully translated to the rearing concrete tanks in black greenhouse. Each fish sex was separately stocked into the rearing concrete tanks for two weeks as an adaptation period. During this period, fish fed a diet containing $45 \%$ crude protein and $12 \%$ crude fat produced by Aller Aqua for extruded marine fish feed, Christiansfeld, Denmark.
Concrete tanks $(4 \mathrm{~m} \times 8 \mathrm{~m} \times 1 \mathrm{~m})$ and 32000 liters capacity in black greenhouse, continuous aeration was maintained in each tank using an electric air blower with 7 HP 3000 RPM, China. The water was received in external reservoir $(12 \times 12 \times 2 \mathrm{~m})$ for sedimentation, after that water was filtered, aerated using mechanical and microbial filters, ionizer and aerator, then water were pumped to the hatchery ponds in the black greenhouse. Filtration was performed using sand filter. Tanks filled with marine water 35 ppt. Water in each tank were changed twice a day by water follow system. Water temperature was adjusted was maintained at $17 \pm 1^{\circ} \mathrm{C}$. Lighting was performed for 10 hours per day from 7 am to $5 \mathrm{pm}$.

In the feeding period, Sea bass brood stock females and males were distributed separately into six experimental treatments (as three replicates per treatment) being three treatments for females and other three treatments for females as shown in Table 1. Thus, a total of 180 Sea bass brood stock females and males were used. The 90 females with $1190-1820 \mathrm{~g}$ per fish as an initial body weight were separately allotted in 9 concert tanks (three tanks / treatment). Also, 90 males with initial body weight ranged between $(880-1400 \mathrm{~g}$ per fish) separately allotted in other 9 concert tanks Fish were stocked at 10 fish per concrete tank $(4 \mathrm{~m} \times 8 \mathrm{~m} \times 1 \mathrm{~m})$ in black greenhouse at the same experimental conditions.

Fish were fed the trash fish (sardine and calamari), which are consider as the common feed for brood stock in Egyptian marine fish hatcheries. Fresh sardine and frozen calamari were bought from Al-Max fishing board, Alexandria Governorate, Egypt. Prior to use, the trash fish was crumbled to small pieces as an appropriate size and stored frozen $\left(-20^{\circ} \mathrm{C}\right)$ until required. The floating artificial diet was prepared in the feed factory at Al-Max research station, National Institute of Oceanography and Fisheries (NIOF), Alexandria Governorate, Egypt. Artificial diet ( $48 \%$ crude protein and $15 \%$ crude fat) was prepared to be of the nearly similar chemical composition of the trash fish (Tables 2 and 3).

Artificial diet was extruded as floating pellets, $1 \mathrm{~cm}$ in diameter, and coated with fish oil after drying. Fish were fed the trash fish diet and their mixing with the artificial diet $(50 \%: 50 \%)$ at a rate of $2.5 \%$ of their body weight, while fish fed the artificial diet at a rate of $1 \%$ of their body weight. The feed quantity was adjusted bi-weekly according to the actual body weight changes. All the experimental diets manually introduced to the fish twice daily at 8 am and $2 \mathrm{pm}$. 
Table 1. Details of the experimental treatments design in the feeding period.

\begin{tabular}{|c|c|}
\hline Treatment & Details \\
\hline $\mathrm{T}_{1}, q$ & Females fed the trash fish (sardine and calamari) as a control group \\
\hline $\mathrm{T}_{2}$, q & Females fed the mixing of trash fish and artificial diet (50\%:50\%). \\
\hline $\mathrm{T}_{3}$, + & Females fed a floating artificial diet \\
\hline $\mathrm{T}_{4}, \hat{0}^{\lambda}$ & Males fed the trash fish (sardine and calamari) as a control group \\
\hline $\mathrm{T}_{5}, \hat{0}$ & Males fed the mixing of trash fish and artificial diet $(50 \%: 50 \%)$. \\
\hline $\mathrm{T}_{6}, \hat{\jmath}$ & Males fed a floating artificial diet \\
\hline
\end{tabular}

Table 2. Feed ingredients (\%) of the artificial diet used during the feeding period.

\begin{tabular}{ll}
\hline Ingredient & $\%$ \\
\hline Fish Meal $999(72 \%, \mathrm{CP})$ & 21.00 \\
Fish Meal $(65 \%, \mathrm{CP})$ & 15.00 \\
Soy bean meal $(48 \%, \mathrm{CP})$ & 25.00 \\
Corn gluten $(60 \%, \mathrm{CP})$ & 10.00 \\
Sun flour meal $(36 \%, \mathrm{CP})$ & 8.50 \\
Wheat middling $(13 \%, \mathrm{CP})$ & 6.00 \\
Fish oil & 12.00 \\
Wheat gluten $(80 \%, \mathrm{CP})$ & 1.00 \\
Animal gelatin & 0.25 \\
Mono calcium & 0.50 \\
Vitamins premix ${ }^{1}$ & 0.25 \\
Minerals premix ${ }^{2}$ & 0.25 \\
Lysine & 0.10 \\
Methionine & 0.10 \\
Vitamin C & 0.05 \\
Total & 100 \\
\hline
\end{tabular}

${ }^{1}$ Vitamins (per kg feed): Vit. A (1,000,000 IU); Vit. D3 (85.714 IU); Vit. E (100,000 IU); Vit. B1 (5,000 mg); Vit. B2 (10,000 mg); Vit. B6 (10,000 mg); Vit. B12 (10,000 mg); Vit. C (20,000 mg); Biotin (500 mg); folic acid (2,000 mg); pantothenic acid $(20.000 \mathrm{mg})$, and Vit. $\mathrm{K}_{3}(2,000 \mathrm{mg})$.

${ }^{2}$ Minerals (per kg feed): $\mathrm{Ca} \mathrm{CO}_{3}\left(314 \mathrm{mg}\right.$ ); $\mathrm{KH}_{3} \mathrm{PO}_{4}$ (469.2 mg); $\mathrm{Mg} \mathrm{SO}_{4} .7 \mathrm{H}_{2} \mathrm{O}$ (147.4mg); Na Cl, (49.8 mg); Trace elements $19.6 \mathrm{~g}$ consists of $\mathrm{Fe}^{+2}$ - gluconate; $\mathrm{Mn} \mathrm{SO}_{4} \cdot \mathrm{H}_{2} \mathrm{O}(10900 \mathrm{mg}) ; \mathrm{Zn} \mathrm{SO}_{4} .7 \mathrm{H}_{2} \mathrm{O}(3120 \mathrm{mg}) ; \mathrm{Cu} \mathrm{SO}_{4} .5 \mathrm{H}_{2} \mathrm{O}(620$

$\mathrm{mg}$ ); KI: (160 mg); $\mathrm{Cl} \mathrm{CO}_{3} .6 \mathrm{H}_{2} \mathrm{O}$; Ammonium molybdate $\left(60 \mathrm{mg}\right.$ ), and $\mathrm{Na}_{2} \mathrm{SeO}_{3}$ (Sodium selenate) $(20 \mathrm{mg}$ ).

Table 3. The chemical composition of the experimental diets used during the feeding period.

\begin{tabular}{|c|c|c|c|c|}
\hline Chemical composition & Artificial diet & Sardine & Calamari & Sardine + Calamari \\
\hline Dry mater $(\%)$ & 91.29 & 27.60 & 21.80 & 23.70 \\
\hline Crude protein (\%) & 47.94 & 39.80 & 51.60 & 47.20 \\
\hline Crude fat $(\%)$ & 15.41 & 9.81 & 9.00 & 10.22 \\
\hline Ash (\%) & 6.90 & 12.98 & 8.88 & 9.32 \\
\hline Crude fiber $(\%)$ & 2.10 & Nil & Nil & Nil \\
\hline Nitrogen free extract (NFE, \%) & 27.65 & 37.41 & 30.52 & 33.26 \\
\hline Gross energy (Kcal / 100 g DM) (GE) ${ }^{1}$ & 2215.38 & 1969.91 & 2097.89 & 2089.32 \\
\hline $\begin{array}{l}\text { Protein / energy (P / E) ratio } \\
\text { (mg CP / KJ GE) }\end{array}$ & 21.63 & 20.20 & 24.59 & 22.59 \\
\hline $\begin{array}{l}\text { Metabolizable energy }(\mathrm{ME})^{2} \\
(\mathrm{KJ} / 100 \mathrm{~g} \mathrm{DM})\end{array}$ & 1828.57 & 1628.07 & 1805.85 & 1720.67 \\
\hline
\end{tabular}


During the feeding period, water temperature, dissolved oxygen (DO), $\mathrm{pH}$ and salinity were monitored twice daily at $15 \mathrm{~mL}$ depth using Crison Meters, Spain. While, unionized ammonia was measured twice weekly using HI 96700 Ammonia Low Range Portable Photometer Hanna, India. In all treatments, DO concentration ranged from $4-7.5 \mathrm{mg} / \mathrm{L}$, $\mathrm{pH}$ ranged between was $6.8-8.4$ unionized ammonia concentration range was $0.33-1.5$ $\mathrm{mg} / \mathrm{L}$, Salinity range was $34 \pm 2.0 \mathrm{~g} / \mathrm{L}$ and temperature rang was $16 \pm 1.0^{\circ} \mathrm{C}$. These water quality parameters were accepted for rearing Sea bass brood stock according to Moretti et al. (1999).

Directely after the feeding period, the spawning period for 15 days was beginning, where the canuola test was conducted of European Sea bass brood stock females in each treatment to examine maturity of the eggs (as egg diameter $550-650 \mu \mathrm{m}$ according to Moretti et al. (1999), unstuck eggs. Then the maturation brood stock females were injected with 1000 IU hCG per kg body weight (Argent ${ }^{\circledR}$, USA, according to Moretti et al., 1999). The concrete tanks were carefully cleaned before the spawning period. Then, females and males brood stock of each treatment (as three treatments) were stocked at $1: 1$ as a sex ratio in the cleaning concrete tanks for $48 \mathrm{hrs}$.

At the end of the feeding period, six fish $(n=6)$ from each treatment were randomly chosen and anaesthetized. Fish were anaesthetized by transferred in a small plastic tank containing $10 \mathrm{~L}$ water supplemented with $3 \mathrm{~mL}$ pure clove oil dissolved in 10 $\mathrm{mL}$ absolute ethanol. Then, the brood stock females and males weight and total length were taken for the nearest $0.1 \mathrm{~g}$ and $0.01 \mathrm{~cm}$, respectively (Fig. $26 \mathrm{a} \& \mathrm{~b}$ ) to calculate the condition factor $\left(\mathrm{K}_{\mathrm{f}}\right)$ according to the following equation; $\mathrm{K}_{\mathrm{f}}=\mathrm{W} / \mathrm{L}^{3} \times 100$ described by Lagler (1956). Where, $\mathrm{W}$ is a fish weight (wet weight in $\mathrm{g}$ ) and $\mathrm{L}$ is a fish total length (in $\mathrm{cm}$ ). After that the same fish were killed and the abdominal cavity was opened to remove the gonads (male and female) or the liver. Which were individually weighed to calculate the gonado somatic index (GSI) and hepato somatic index (HSI) by the following equations; GSI = gonads weight $\times 100 /$ fish weight (Tseng and Chan, 1982), and HSI = (liver weight / fish weight) $\times 100$ (Jangaard et al., 1967).

At the start and at the end of the feeding period, fish were anaesthetized and sacrificed to examine the development of the ovary and the status of the liver in all treatments, which were recorded by the digital camera. Then, the histological changes in the ovary and the liver after the feeding period were checked. The same fish at the same numbers $(n=6)$ used for determined the $\mathrm{K}_{\mathrm{f}}$, GSI and HSI or the anatomical alterations were taken for histological examination. Fish were anaesthetized and sacrificed to obtain the ovaries and the livers samples. Samples were fixed in $10 \%$ neutralized formalin solution followed by washing with tab water, then dehydrated by different grades of alcohol (70, 85, 96 and 99\%). Samples were cleared by xylene and embedded in paraffin wax. The wax blocks were sectioned to six micron. The sections were stained by hematoxyline $(\mathrm{H})$ and eosin (E) and then subjected to a histological examination according to Roberts (2001).

\section{Statistical analysis}

Data of $\mathrm{K}_{\mathrm{f}}$, GSI and HSI were reported as mean values of all treatments. Replications $(n=3)$ and standard errors of mean $( \pm$ SEM) are based on tank values. All percentages were arcsine-transformed prior to statistical analyses. All data were subjected to one-way analysis of variance (ANOVA) using SPSS for windows (Standard version 17.0 SPSS Inc., Chicago, Illinois, USA). The differences between mean of treatments were compared for the significance $(p \leq 0.05)$ using Tukey's post hoc significant test.

\section{Results and discussion}

\section{Condition factor $\left(K_{f}\right)$ and organs indices parameters}

In females fed the artificial diet, or fed trash fish only (sardine and calamari) $T_{3}$ and $T_{1}$, respectively were significantly $(p \leq 0.05)$ increased the $\mathrm{K}_{\mathrm{f}}$ compared to the fish fed the mixing of trash fish and artificial diet $(50 \%+$ $\left.50 \%, \mathrm{~T}_{2}\right)$. Also, Sea bass female fed the artificial diet $\left(\mathrm{T}_{3}\right)$ significantly $(p \leq 0.05)$ increased GSI compared to fish fed the other dietary treatments $\left(\mathrm{T}_{1}\right.$ and $\left.\mathrm{T}_{2}\right)$. Meanwhile, no significant $(p \geq 0.05)$ differences of HSI among all dietary treatments (Table 4).

However, data indicated that $\mathrm{K}_{\mathrm{f}}$ of D. labrax brood stock males fed the different experimental diets $\left(\mathrm{T}_{4}, \mathrm{~T}_{5}\right.$, and $\left.\mathrm{T}_{6}\right)$ did not significantly $(p \geq 0.05)$ differ after 45 days of treatment. Sea bass male fed the trash fish $\left(\mathrm{T}_{4}\right)$ revealed that significantly $(p \leq 0.05)$ increased HSI compared to fish fed the other dietary treatments $\left(\mathrm{T}_{5}\right.$ and $\left.\mathrm{T}_{6}\right)$. Meanwhile, no significant $(p \geq 0.05)$ differences of GSI among all dietary treatments (Table 4). 
Table 4. Effect of dietary treatments on condition factor (Kf), gonadosmatic index (GSI), and hepatosomatic index (HSI) of female and male Sea bass (D. labrax) brood stock

\begin{tabular}{|c|c|c|c|}
\hline Treatment & Condition factor $\left(K_{f}\right)$ & GSI (\%) & HSI (\%) \\
\hline $\mathbf{T}_{\mathbf{1}}$, 우 & $1.24 \pm 0.384^{\mathrm{a}}$ & $7.8 \pm 0.379^{\mathrm{ab}}$ & $5.1 \pm 0.369$ \\
\hline $\mathbf{T}_{\mathbf{2}}$, 우 & $1.04 \pm 0.021^{\mathrm{b}}$ & $6.7 \pm 0.205^{\mathrm{b}}$ & $5.3 \pm 0.259$ \\
\hline $\mathbf{T}_{3}$, 우 & $1.30 \pm 0.038^{\mathrm{a}}$ & $8.3 \pm 0.424^{\mathrm{a}}$ & $6.2 \pm 0.525$ \\
\hline$P$-value & 0.0001 & 0.044 & 0.173 \\
\hline $\mathbf{T}_{\mathbf{4}}, \hat{\sigma}$ & $1.21 \pm 0.019$ & $1.7 \pm 0.235$ & $1.1 \pm 0.149^{\mathrm{a}}$ \\
\hline $\mathbf{T}_{5}, \lambda$ & $1.17 \pm 0.022$ & $1.4 \pm 0.081$ & $0.7 \pm 0.006^{\mathrm{ab}}$ \\
\hline $\mathbf{T}_{6},{ }^{\lambda}$ & $1.21 \pm 0.019$ & $1.3 \pm 0.021$ & $0.6 \pm 0.047^{b}$ \\
\hline$P$-value & 0.190 & 0.177 & 0.042 \\
\hline
\end{tabular}

Mean in the same column having different small letters are significantly different $(p \leq 0.05)$. $\mathrm{T}_{1}$ and $\mathrm{T}_{4}$ : fish fed trash fish (sardine and calamari), $\mathrm{T}_{2}$ and $\mathrm{T}_{5}$ : fish fed the mixing of trash fish and artificial diet $(50 \%+50 \%)$, and $\mathrm{T}_{3}$ and $\mathrm{T}_{6}$ : fish fed a floating artificial diet for females and males, respectively.

\section{Anatomical examination}

The anatomical alterations of the ovary of female Sea bass (D. labrax) brood stock pre and after fed dietary treatments were detected (Fig. 1 a - d). Where, the dietary treatments (Fig. 1 b, c, and d) revealed sharply development of the ovary than the ovary of fish pre treatments (Fig. 1 a). Partially, fish fed the artificial diet $\left(\mathrm{T}_{3}\right)$ showed more development of the ovary than fish fed other dietary treatments $\left(\mathrm{T}_{1}\right.$ and $\left.\mathrm{T}_{2}\right)$. The anatomical alterations of the testes of male Sea bass (D. labrax) brood stock pre and after fed dietary treatments were detected (Fig. $2 \mathrm{a}-\mathrm{d}$ ). Where, the dietary treatments (Fig. 2 b, c, and d) revealed sharply development of the testes than of fish pre treatments (Fig. 2 a). Partially, fish fed the artificial diet $\left(\mathrm{T}_{6}\right)$ showed more development of the testes than fish fed other dietary treatments $\left(\mathrm{T}_{4}\right.$ and $\left.\mathrm{T}_{5}\right)$.

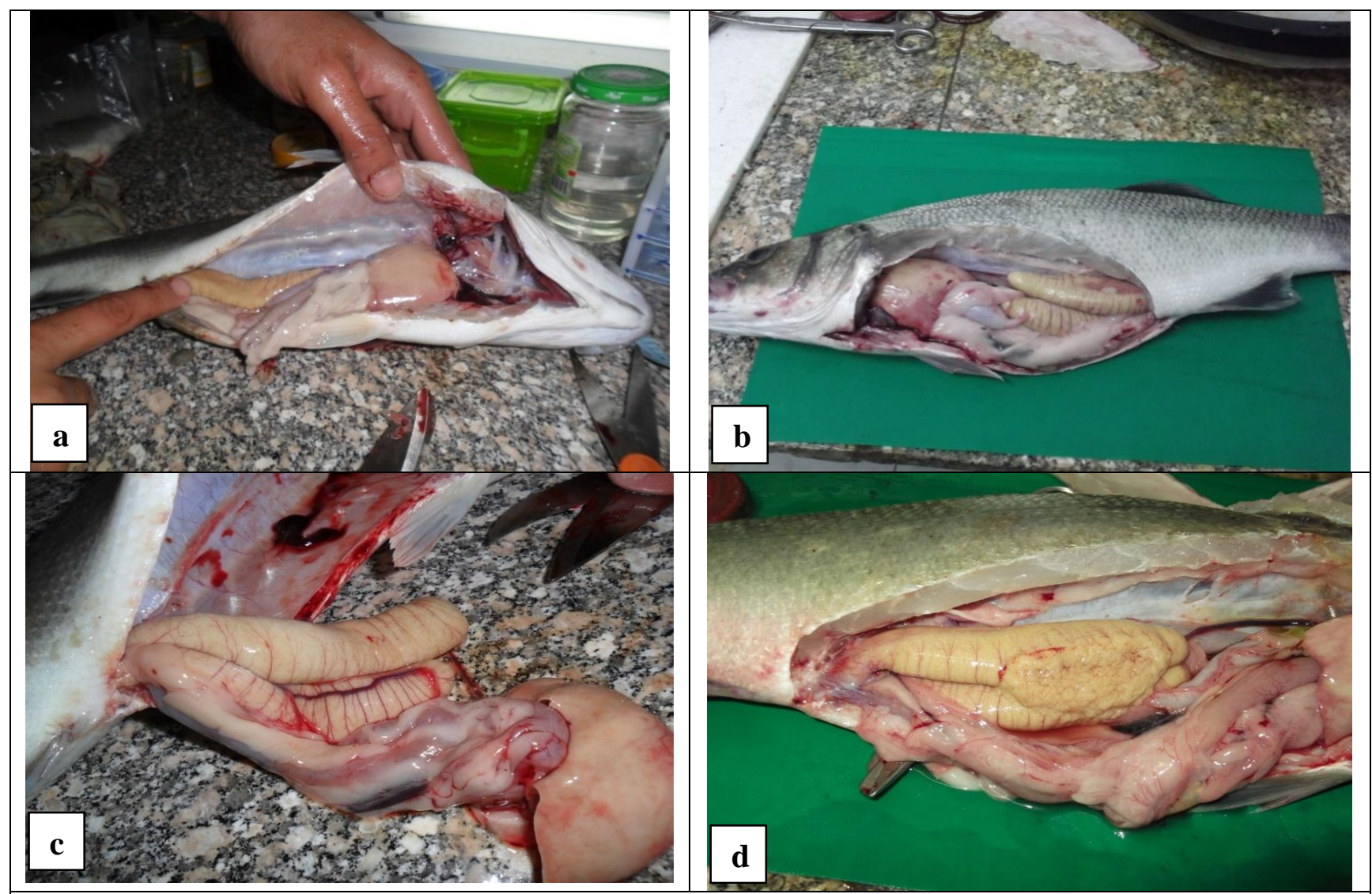

Fig.1 a - d: Showing the anatomical alterations of the ovary of female Sea bass (D. labrax) brood stock (a) pre dietary treatments, and (b, c, and d) after fed the trash fish (sardine and calamari, $\mathrm{T}_{1}$ ), fed the mixing of trash fish and artificial $\operatorname{diet}\left(50 \%+50 \%, \mathrm{~T}_{2}\right)$, and fed a floating artificial diet $\left(\mathrm{T}_{3}\right)$, respectively. 


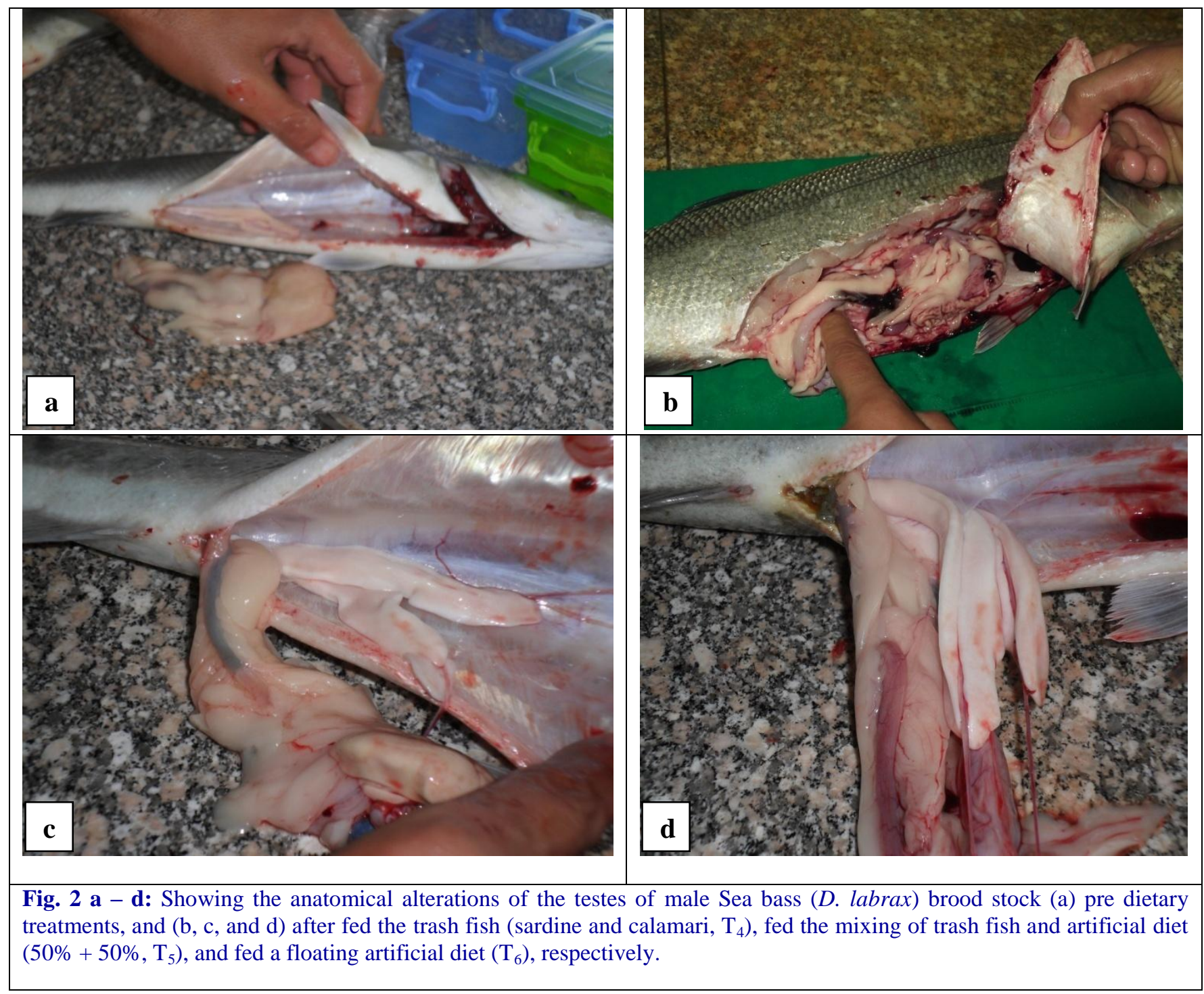

\section{Histological characteristics}

\section{The ovary}

The histological alterations of the ovary of Sea bass (D. labrax) brood stock fed different dietary treatments were showed in Figs. 3 - 5. Microscopically, fish fed the trash fish (sardine and calamari, $\mathrm{T}_{1}$ ) showed the ovary with degenerated mature oocytes follicles and ruptured thecal layer, as well as very low content of yolk globules (Fig. $3 \mathrm{a}-\mathrm{b}$ ). Fish fed the mixing of trash fish and artificial diet $\left(50 \%+50 \%, \mathrm{~T}_{2}\right)$ showed the ovary with irregular mature follicles, dematuration thecal layer and fair content of yolk globule (Fig. $4 \mathrm{a}-\mathrm{b}$ ) Meanwhile, fish fed the floating artificial diet $\left(\mathrm{T}_{3}\right)$ showed normal ovary with mature follicles, normal thecal layer and high content of yolk globule (Fig. $5 \mathrm{a}-\mathrm{b}$ ).

\section{The liver}

The histological examination of the liver of female Sea bass (D. labrax) brood stock fed different dietary treatments was done too and showed in Figs. 6 - 8 . Where, fish fed the trash fish $\left(\mathrm{T}_{1}\right)$ showed dearrangement hepatocytes, the hepatocyte lining is simple layered, low glycogen content, as well as necrosis in hepatocytes was detected (Fig. $6 \mathrm{a}-\mathrm{c}$ ). Fish fed the mixed artificial diet and trash fish (50\%: 50\%) $\left(\mathrm{T}_{2}\right)$ showed slightly dearrangement hepatocytes, the hepatocyte lining is simple layered, normal sinusoids, slight low glycogen content, besides the slight necrosis in hepatocytes (Fig. 7 $\mathrm{a}-\mathrm{b})$. Meanwhile, fish fed the floating artificial diet $\left(\mathrm{T}_{3}\right)$ showed normal hepatocytes, the hepatocyte lining is simple layered, normal sinusoids and improvement of glycogen content in the hepatocytes (Fig. $8 \mathrm{a}-\mathrm{b}$ ). 

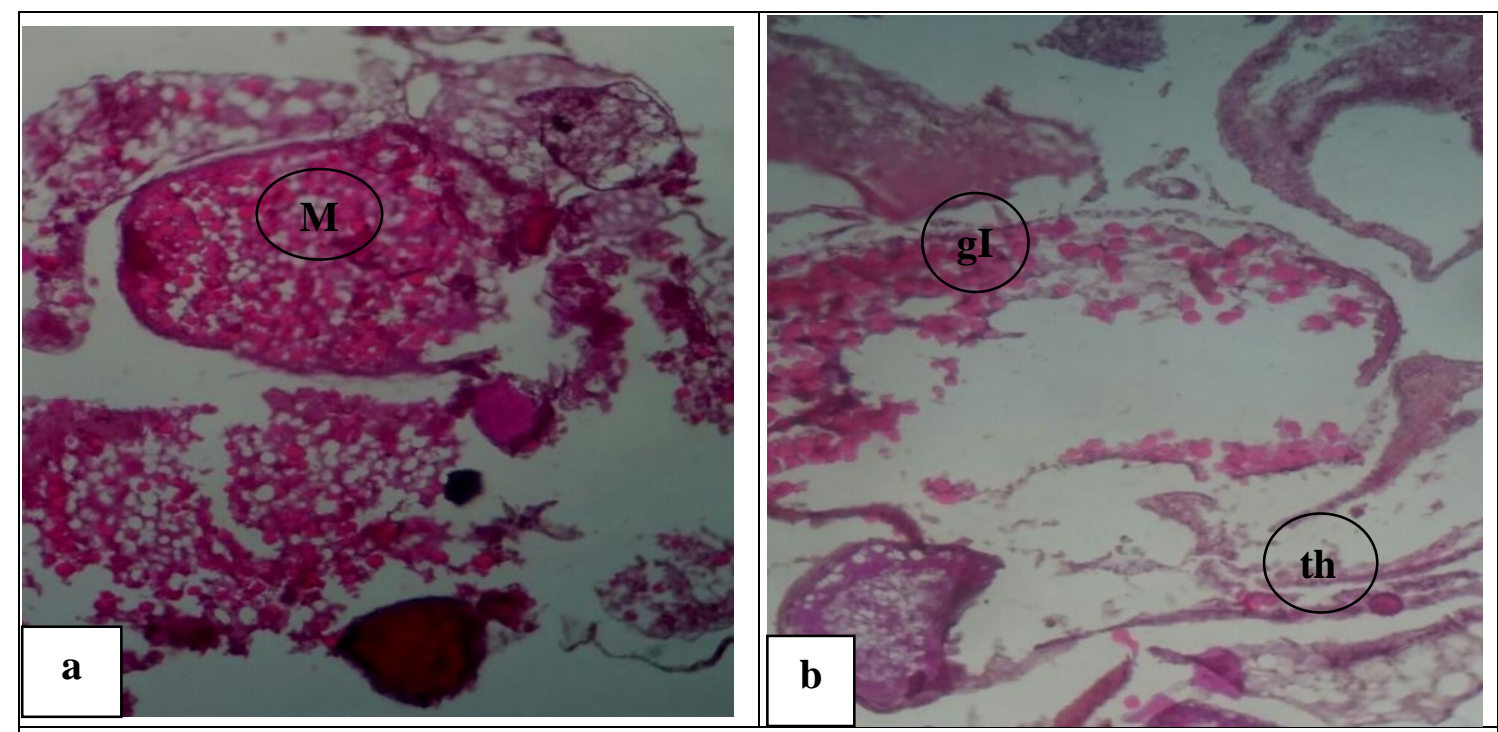

Fig. 3 a - b: Photomicrograph of ovary of Sea bass brood stock fed the trash fish $\left(\mathrm{T}_{1}\right)$ showing ovary with degenerated mature $(\mathrm{M})$ oocytes follicles and ruptured thecal layer (th), very low content of yolk globules $(\mathrm{gl})$, stained with H \& E $(\times 250)$.

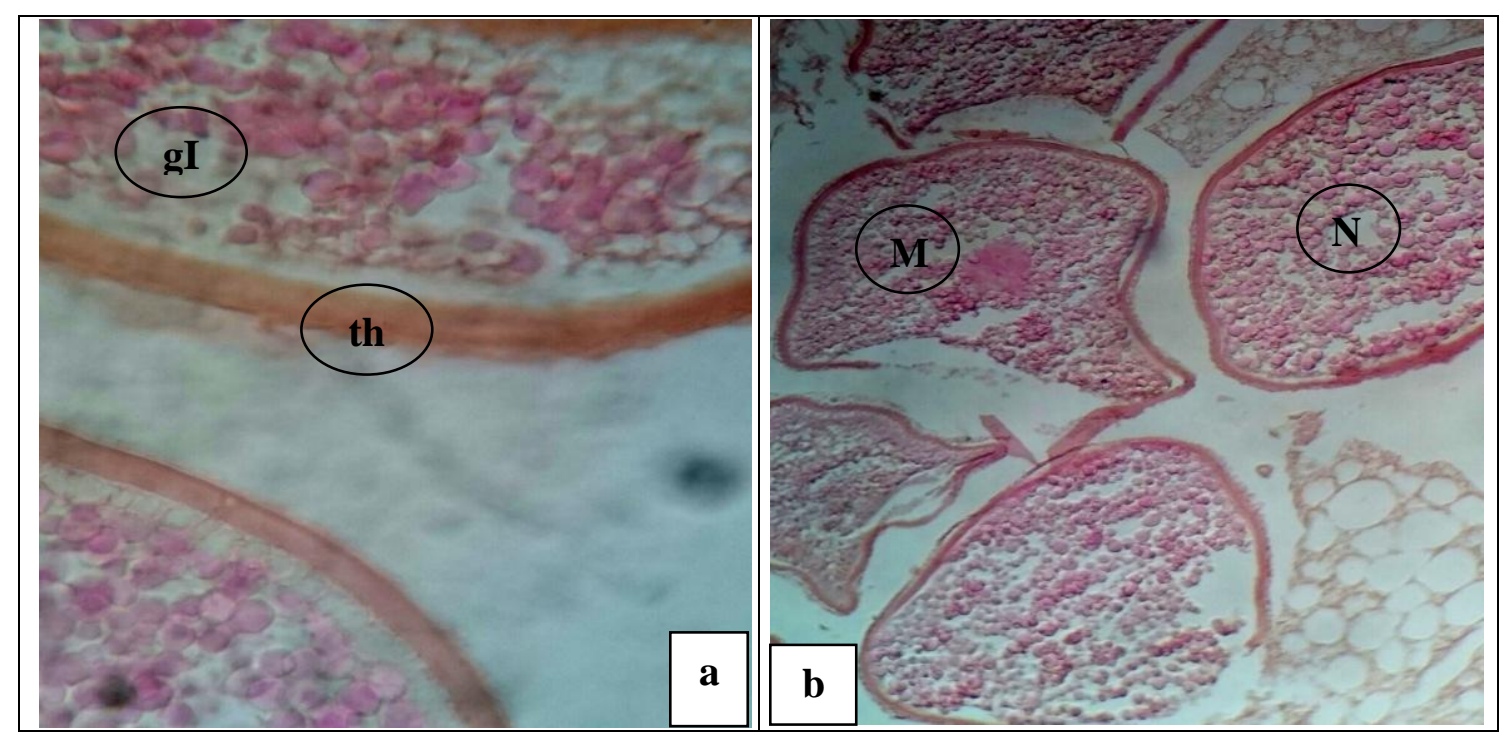

Fig. 4 a - b: Photomicrograph of ovary of Sea bass brood stock fed mixed artificial diet and trash fish $(50 \%: 50 \%)\left(\mathrm{T}_{2}\right)$ showing ovary with irregular mature $(\mathrm{M})$ follicles, dematuration thecal layer (th) and fair content of yolk globule $(\mathrm{gl})$, stained with $\mathrm{H} \& \mathrm{E}(\mathrm{a}, \times 400$, and $\mathrm{b}, \times 250)$. 


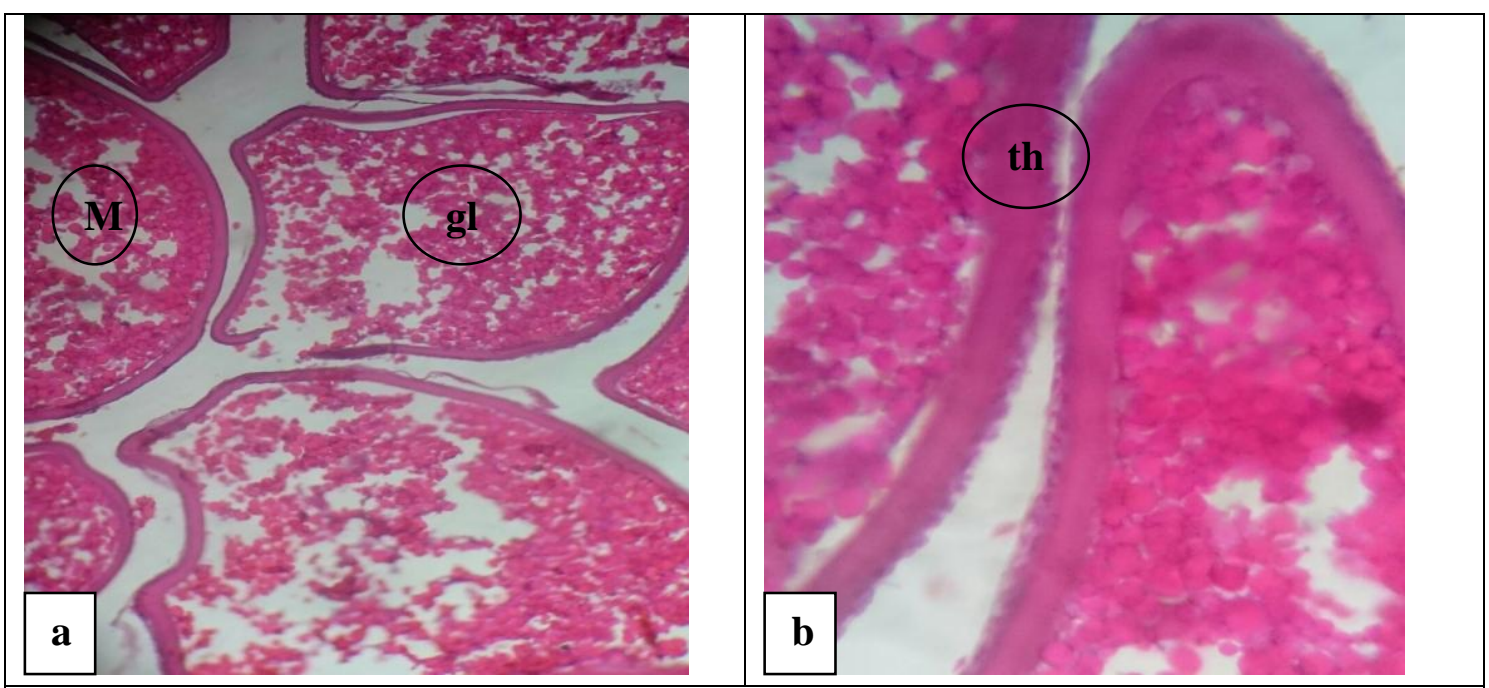

Fig. 5 a - b: Photomicrograph of ovary of Sea bass brood stock fed floating artificial diet $\left(\mathrm{T}_{3}\right)$ showing normal ovary with mature (M) follicles, normal thecal layer (th) and high content of yolk globule (gl), stained with $\mathrm{H} \& \mathrm{E}(\mathrm{a}, \times 250$ and $\mathrm{b}, \times 400)$.
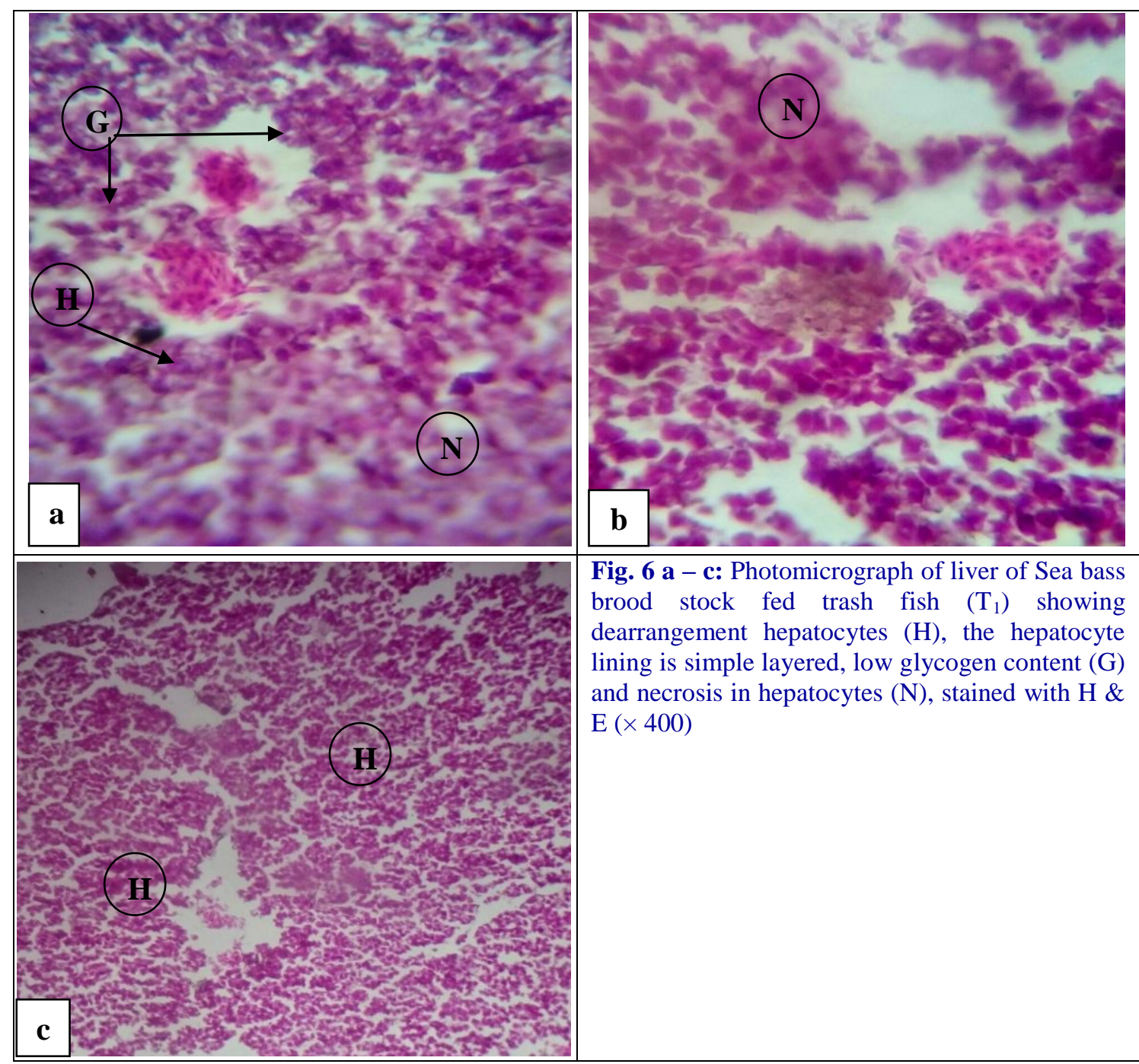

Fig. 6 a - c: Photomicrograph of liver of Sea bass brood stock fed trash fish $\left(\mathrm{T}_{1}\right)$ showing dearrangement hepatocytes $(\mathrm{H})$, the hepatocyte lining is simple layered, low glycogen content $(\mathrm{G})$ and necrosis in hepatocytes $(\mathrm{N})$, stained with $\mathrm{H} \&$ $\mathrm{E}(\times 400)$ 


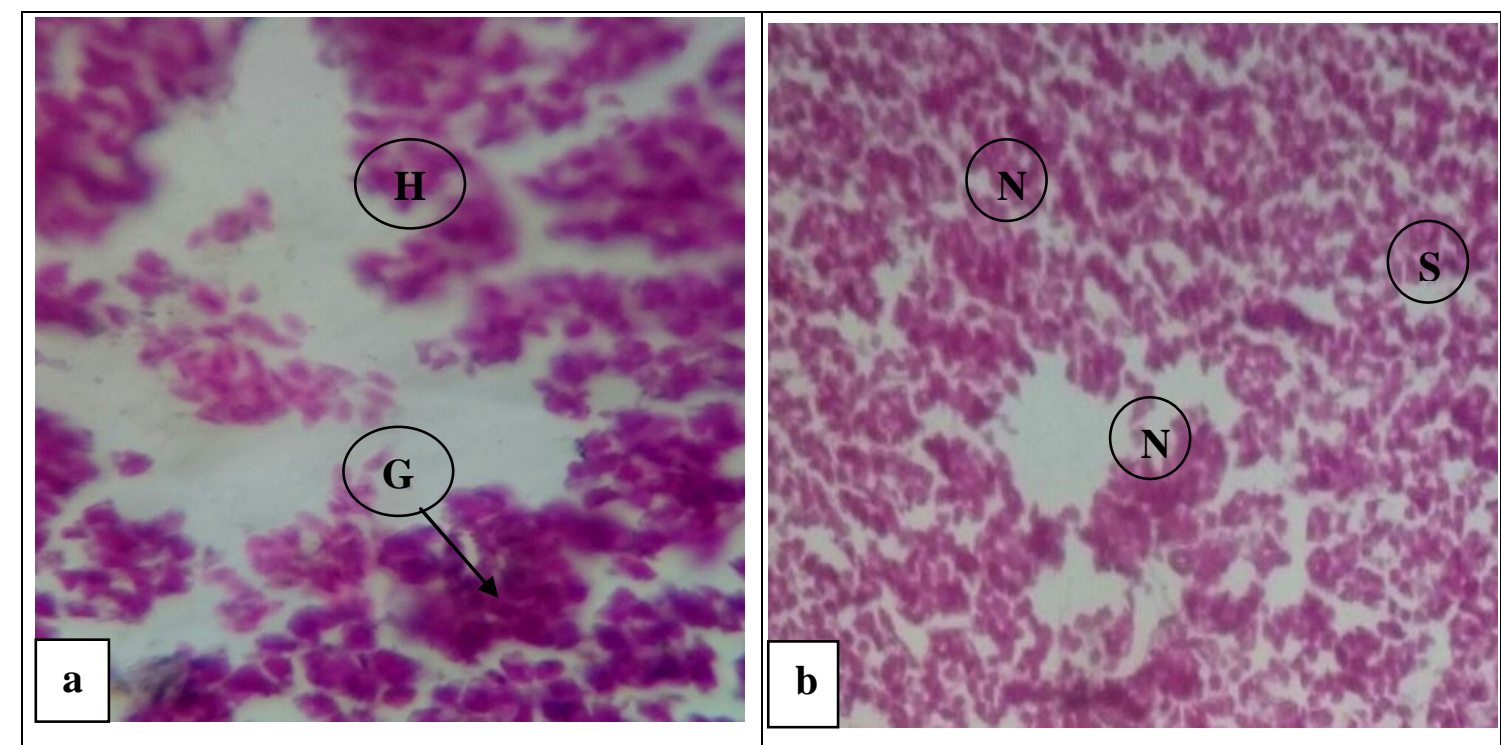

Fig. 7 a - b: Photomicrograph of liver of Sea bass brood stock fed mixed artificial diet and trash fish $(50 \%: 50 \%)\left(\mathrm{T}_{2}\right)$ showing slightly dearrangement hepatocytes $(\mathrm{H})$, the hepatocyte lining is simplelayered, normal sinusoids (S), slight low glycogen content $(\mathrm{G})$ and slight necrosis in hepatocytes $(\mathrm{N})$, stained with $\mathrm{H} \& \mathrm{E}(\mathrm{a}, \times 400$ and $\mathrm{b}, \times 100)$.

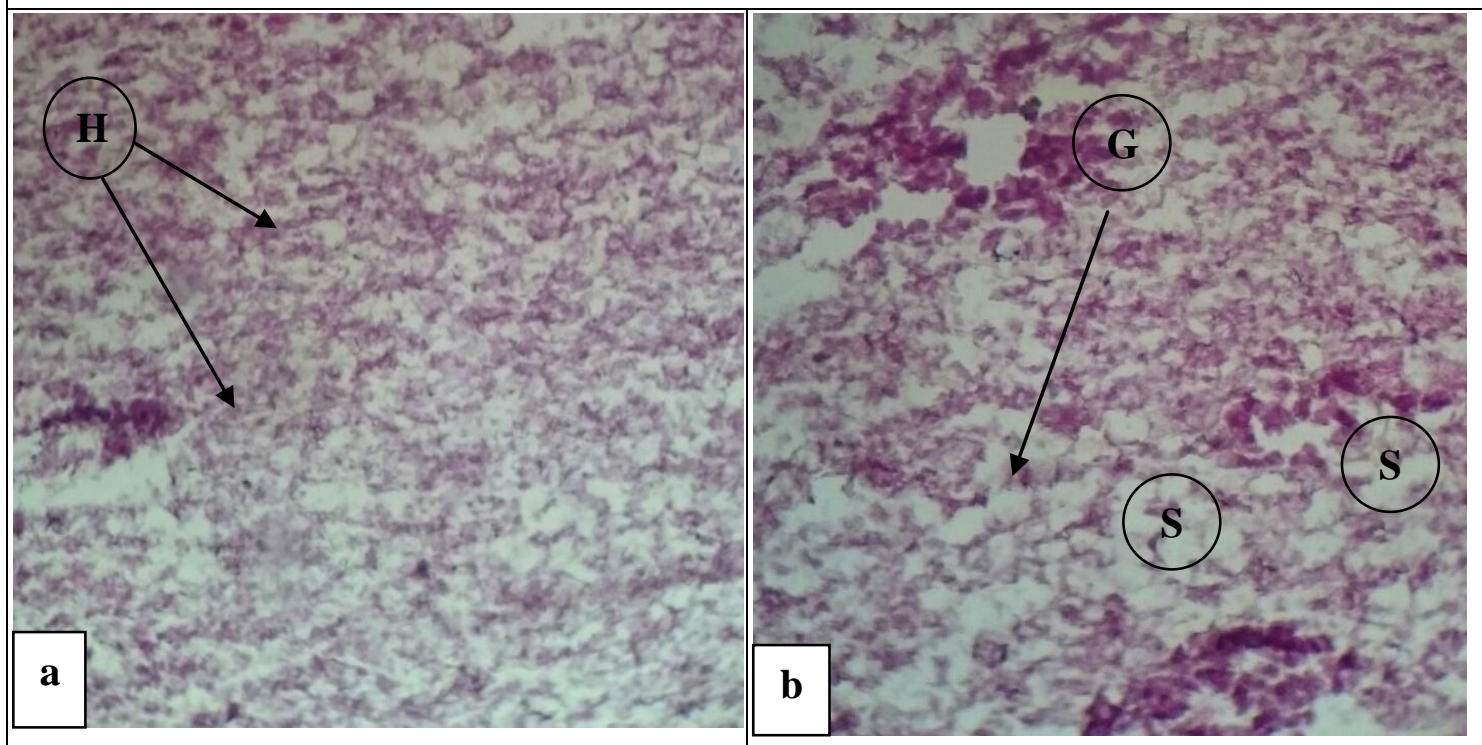

Fig. 8 a - b: Photomicrograph of liver of Sea bass brood stock fed floating artificial diet $\left(\mathrm{T}_{3}\right)$ showing normal hepatocytes $(\mathrm{H})$, the hepatocyte lining is simple layered, normal sinusoids $(\mathrm{S})$ and improvement of glycogen content $(\mathrm{G})$, stained with $\mathrm{H} \& \mathrm{E}(\mathrm{a}, \times 100$ and $\mathrm{b}, \times 400)$.

Condition factor $\left(\mathrm{K}_{\mathrm{f}}\right)$ and length-weight relationship (LWR) are two important parameters for studying the growth, rate of feeding, metamorphosis, fatness, onset of maturity, gonadal development and general well being of the fish population (Araneda et al., 2008). In the present study, European Sea bass (D. labrax) brood stock female fed the artificial diet $\left(\mathrm{T}_{3}\right)$ had improved the $\mathrm{k}_{\mathrm{f}}$ among other dietary treatments. Where, higher $\mathrm{k}_{\mathrm{f}}$ indicated good health with an isometric growth, which is desirable for fish in fish farms (Ayode, 2011). This superiority of the artificial diet may be related with its high quality components and nutrients composition (Tables 2 and 3 ).

Although males use less energy for gonad maturation than females (Jonsson et al., 1991), as well as it is plausible that the amount of surplus energy available 
(from a different diet) to improve their $\mathrm{K}_{\mathrm{f}}$ is higher. Moreover, males generally utilize less energy for gonad maturation than females (Jonsson et al., 1991), as well as males of European sea bass grow 20-40\% less than females (Mylonas et al., 2003). In the present study, no significant differences on the male's $K_{f}$ were found among dietary treatments (Table 4). Furthermore, male gonadal tissue does not occupy the body cavity to the same extent as that of a female during later stages of annual reproductive development. Thus, there is likely to be more space available for food within a male compared to a female's body (Fordham and Trippel, 1999). From other side, Pawson and Pickett (1996) stated that prediction of the initial occurrence of spawning was better correlated to the total length (TL) rather than to $\mathrm{K}_{\mathrm{f}}$ and speculated that spawning could only take place once the Sea bass females had attained TL in excess of $42 \mathrm{~cm}$. Certainly in other fish species such as Atlantic salmon and yellowtail, the condition factor of the fish determines the occurrence of spawning and the fecundity (Venkataramani et al., 1995; Kadri et al., 1996).

Inversely with the obtained results herein, Biswas et al. (2011) reported that the trash fish feeding system could help to produce Asian Sea bass with higher growth, survival and optimum LWR, as well as $\mathrm{K}_{\mathrm{f}}$, as this system better meets up the feed requirement of the growing fish as compared to live prey feeding system. Also, ElHammady et al. (2014) reported that the combination of dry pellet and trash fish have improving in feed efficiency and maximized growth rates in D. labrax, suggesting that mixed diets may better cover the nutritional requirements of $D$. labrax. These differences could be attributed to the species-specific growth rates, losses of feed material during feeding the trash fish (Shapawi et al., 2011). Also, Sim et al. (2005) reported that as much as 30 to $50 \%$ of the trash fish fed to fish can be lost during feeding process.

Quantitative aspects in fishes are important tools for the study of biological fundamentals such as viscerosomatic, hepatosomatic and gonadosomatic indices, because measurement and analysis these indices are very important in assessing food value (Bolger and Connolly, 1989). In the present study, Sea bass female fed the artificial diet $\left(\mathrm{T}_{3}\right)$ increased $(p \leq 0.05)$ GSI compared to fish fed the other dietary treatments $\left(\mathrm{T}_{1}\right.$ and $\mathrm{T}_{2}$, Table 4$)$. While, no significant $(p \geq 0.05)$ differences of GSI among all dietary treatments of Sea bass male. Similarly with the obtained trend herein, Abdelhamid et al. (2010) found that Oreochromis niloticus females have higher values of GSI than males. That is in agreement with EL-
Sayed et al. (2007), who also reported that Tilapia zillii females showed higher GSI values than males during the period from June to September with a peak in July. The positive effect of the artificial diet $\left(\mathrm{T}_{3}\right)$ on GSI of Sea bass female in the current findings as a positive correlation of the superiority effects of this treatment $\left(\mathrm{T}_{3}\right)$ on $\mathrm{K}_{\mathrm{f}}$ among all dietary treatments. Generally, determination of the reproductive maturity using GSI only is not enough, because the structures within the ovary, such as oocytes at different stages, interstitial tissue with accumulation of yolk materials, cannot be interpreted by weight. Direct observation of histological architecture is the most accurate method to let us know exactly the stage of maturation at which the ovary is undergoing.

In case of Sea bass male fed the trash fish $\left(\mathrm{T}_{4}\right)$ increased $(p \leq 0.05)$ HSI compared to fish fed the other dietary treatments $\left(\mathrm{T}_{5}\right.$ and $\left.\mathrm{T}_{6}\right)$, but in case of Sea bass female no significant $(p \geq 0.05)$ differences of HSI among all dietary treatments (Table 4). HSI-values observed in the present study are within the range of values previously reported for European Sea bass (Tibaldi et al., 1991; Dias et al., 1998). HSI higher than 2 was noted by Metailler et al. (1981) in Sea bass fed diets containing more than $14 \%$ fat, and by Spyridakis et al. (1986) using diets with a starch level higher than 16\%. However, Seung-Cheol et al. (2007) reported that no significant differences were detected of HSI values of red Sea bream, Pagrus major fed mixture of four supplemented medicine herbs compared to the control group. In rainbow trout, it has been observed that feeding high levels of digestible carbohydrate increases liver size and glycogen content (Pieper and Pfeffer, 1979; Hilton and Atkinson, 1982).

Gonadal maturation of European Sea bass brood stock can be arrested by reduced feeding rations (Chatzifotis et al., 2011). Nutrition of brood stock has a profound effect on gonadal maturation and fecundity (Watanabe, 1988), and plays a major role in reproductive success in both fish and crustaceans (Takeuchi et al., 1981; Teshima and Kanazawa, 1983; Watanabe et al., 1984). Histological examination is the most accurate tool to determine the reproductive state of female fish (West, 1990). In the present study, the anatomical development of female and male Sea bass was detected. Where, dietary treatments (Fig. 1 b, c, and d) revealed sharply development of the ovaries or the testes than of fish pre treatments (Fig. 1 a). Partially, female or male fed the artificial diet $\left(\mathrm{T}_{3}\right.$ and $\mathrm{T}_{6}$, respectively) showed more development of the gonads than fish fed other dietary treatments. These seriously development of fish gonads were confirmed by the histological examination of the gonads and the liver too. 
These superiority of the artificial diet regarding the anatomical and histological alterations of the fish gonads and the liver are not surprising. Where, these helpful effects on anatomical and histological examinations were confirmed by the positive effects on $\mathrm{K}_{\mathrm{f}}$, GSI and HSI parameters (Table 4). Where, morphological, and biological characteristics of the resulting progeny are direct or indirect consequences of the previous nutrition of the brood fish during some time before the reproductive process can take place. Consequently, if the previous nutrition of brood fish is adequate, the resulting eggs can be of good quality and will have all the potential to produce viable fry (Carrillo et al., 2000). During oogenesis, oocytes are divided into various stages depending on the morphology of the nucleus, cytoplasm and follicle. These stages may be grouped into the previtellogenic, vitellogenic, maturation, and atresia phases. Details of each stage are completely documented in Selman and Wallace (1989).

Liver plays a key role in regulating intermediary metabolism in response to nutritional status (Klover and Mooney, 2004). Observations on the histological appearance of the liver tissue herein indicated that no pathological phenomena were present in Sea bass female fed the artificial diet. Where this treatment $\left(\mathrm{T}_{3}\right)$ revealed that normal hepatocytes, the hepatocyte lining is simple layered, normal sinusoids, normal pancreatic acini and improvement of high glycogen content in the hepatocytes (Fig. $8 \mathrm{a}-$ b). Inversely with the current findings, many authors have shown that artificial diets such as dry granules induce hepatic alterations, with excessive fat in the hepatocytes (Acuigrup, 1981; Starch et al., 1983). The unusually pale (nearly white) livers sometimes had a mottled appearance indicative of fatty degeneration.

Generally, the histological examination of the ovary or the liver of Sea bass brood stock fed the experimental diets revealed the positive alterations, especially for fish fed the floating artificial diet $\left(\mathrm{T}_{3}\right)$ than those fed the trash fish (sardine and calamari, $\mathrm{T}_{1}$ ), or fed the mixed artificial diet and trash fish $\left(50 \%: 50 \%, \mathrm{~T}_{2}\right)$. These positively effects of dietary treatments on histological alterations of the ovary or the liver were potentially related with the anatomical modifications (Fig. 1), or $\mathrm{K}_{\mathrm{f}}$, GSI and HSI (Table 4).

From other side, in the present study Sea bass female fed other dietary treatments showed some histopathologic findings of the liver (Figs. 6 and 7) such as, dearrangement hepatocytes, the hepatocyte lining is simple layered, low glycogen content, necrosis in the hepatocytes. In these dietary treatments elevation is characteristic of liver damage, were well correlated with the histopathologic findings of the liver. These impaired alterations in the liver tissue were manifested as an accumulation of lipid globules and a reduction in glycogen reserves (Bat et al., 1983; Starch et al., 1983). This excess fat was correlated with alteration of the lipid metabolism, secondary to a deficiency in essential fatty acids (Roche et al., 1982 a, b; Bat et al., 1983). Moreover, almost every attempt to completely replace fresh food with artificial diets, results in a decrease in ovarian maturation, a reduced number of spawns and an inferior egg quality. In most situations, a combination of fresh food and artificial diets gives better results than a feeding regime that consist of fresh food only (Bray et al., 1990 a, b; Nascimento et al., 1991).

\section{Conclusion}

The obtained findings herein revealed that fish fed the artificial diet positively affects on $\mathrm{K}_{\mathrm{f}}$, GSI and HSI, besides its helpful effects on anatomical and histological examinations of the ovary and the liver among other dietary treatments. Hence, it could be confirmed on the potential relationship between the fish feeding sources and the reproductive efficiency of Sea bass D. labrax brood stock. Based on this positive relationship, the good quality artificial diets must be used in marine fish hatcheries to enhance their reproductive performance. Also, more advanced researches could be conducting to investigate the effect of natural or synthetics feed additives on the reproductive performance of marine fish.

\section{Conflict of interest statement}

Authors declare that they have no conflict of interest.

\section{References}

Abdelhamid, A.M., Mehrim, A.I., El-Barbary, M.I., ElSharawy, M.A., 2010. An attempt to improve the reproductive efficiency of Nile tilapia brood stock fish. Fish Physiol. Biochem. 36(4), 1097-1104.

Acuigrup, J., 1981. Aspects of fish pathology in Spain, with application to other geographic areas. World Conference on Aquaculture, Venice, 2 1-25 September 1981.

Araneda, C., Neira, R., Lam, N., Iturra, P., 2008. Salmonids. In: Genome Mapping and Genomics in Fishes and Aquatic Animals (Eds.: Kocher, T., Kole, C.). Springer Verlag, Berlin. pp.1-43.

Ayode, A. A., 2011. Length-weight relationship and diet of African Carp Labeo ogunensis (Boulenger, 1910) in 
Asejire Lake Southwestern Nigeria. J. Fisheries Aquatic Sci. 1, 816-927.

Bat, N., Biagianti, S., Brusle, J., 1983. Etude cytologique ultrastructurale des anomalies hepatiques du loup, de la daurade et de l'anguille, induites par une alimentation artificielle. IFREMER Actes Colloques. 1, 473-484.

Biswas, G., Thirunavukkarasu, A.R., Sundaray, J.K., Kailasam, M., 2011. Culture of Asian seabass Lates calcarifer (Bloch) in brackish water tide-fed ponds: growth and condition factor based on length and weight under two feeding systems. Indian J. Fish. 58(2), 53-57.

Bolger, T., Connolly, P.L., 1989. The selection of suitable indices for the measurement and analysis of fish condition. J. Fish Biol. 34, 171-182.

Bray, W.A., Lawrence, A.L., Leung-Trujillo, J.R., 1990a. Reproductive performance of ablated Penaeus stylirostris fed a soy lecithin supplement. J. World Aquacult. Soc. 20, 19A.

Bray, W.A., Lawrence, A.L., Lester, L.J., 1990b. Reproduction of eyestalk-ablated Penaeus stylirostris fed various levels of total dietary lipid. J. World Aquacult. Soc. 21, 41-52.

Bromage, N., Jones, J., Randall, C., Thrush, M., Davies, B., Springate, J.R.C., et al., 1992. Broodstock management, fecundity, egg quality and the timing of egg production in the rainbow trout (Oncorhynchus mykiss). Aquaculture. $100,141-166$.

Carrillo, M., Zanuy, S., Oyen, F., Cerdá, J., Navas, J.M., Ramos, J., 2000. Some criteria of the quality of the progeny as indicators of physiological broodstock fitness. In: Recent Advances in Mediterranean Aquaculture Finfish Species Diversification (Ed.: Chioccioli, E.). Cahiers Options Mediterranées. 47, 61-74.

Chatzifotis, S., Papadaki, M., Despoti, S., Roufidou, C., Antonopoulou, E., 2011. Effect of starvation and refeeding on reproductive indices, body weight, plasma metabolites and oxidative enzymes of sea bass (Dicentrarchus labrax). Aquaculture. 316, 53-59.

Dias, J., Alvarez, M.J., Diez, A., Arzel, J., Corraze, G., Bautista, J.M., Kaushik, S.J., 1998. Regulation of hepatic lipogenesis by dietary proteinrenergy in juvenile European seabass Dicentrarchus labrax. Aquaculture. $161,169-186$.

El-Hammady, A.K.I., El-Kasheif, M.A. Ibrahim, S.A., Mohammed A.I.W., 2014. Feeding European Sea bass (Dicentrarchus Labrax) with trash fish. 2- Nutritive utilization and digestive tract. Life Sci. J. 11(9), 584-598.

EL-Sayed, H., Akel, K.H., Moharram, S.G., 2007. Reproductive biology of Tilapia zillii (Gerv, 1848) from Abu Qirbay, Egypt. Egypt. J. Aquatic Res. 33(1), 379394.

FAO, 2012. Fisheries and Aquaculture Department. Dicentrarchus labrax (Linnaeus, 1758). Cultured Aquatic Species Information Programme. Rome, Italy.

Fordham, S.E., Trippel, E.A., 1999. Feeding behaviour of cod (Gadus morhua) in relation to spawning. J. Appl. Ichthyol. 15, 1-9.
Hilton, J.W., Atkinson, J.L., 1982. Response of rainbow trout (Salmo gairdneri) to increased levels of available carbohydrate in practical trout diets. Br. J. Nutr. 47, $597-$ 607.

Jangaard, P.M., Ackman, R.G., Spios, J.C., 1967. Seasonal studies of the fatty acids composition of cod liver flesh, roe and milt lipids. J. Fish Res. Bd. Canada. 24, 613-627.

Jonsson, N., Jonsson, B., Hansen, L.P., 1991. Energetic cost of spawning in male and female Atlantic salmon (Salmo salar L.). J. Fish Biol. 39, 739-744.

Kadri, S., Mitchell, D.E., Metcalfe, N.B., Huntingford, E.A., Thorpe, J.E., 1996. Deferential patterns of feeding and resource accumulation in maturing and immature Atlantic salmon, Salmo salar. Aquaculture. 142(3-4), 245-257.

Kjorsvik, E., Mangor-Jesen, A., Holmefjord, I., 1990. Egg quality in fishes. In: Advances in Marine Biology Vol. 26. Academic Press, London. pp.71-113.

Klover, P.J., Mooney, R.A., 2004. Hepatocytes: critical for glucose homeostasis. Int. J. Biochem. Cell Biol. 36, 753758.

Lagler, K.R., 1956. Freshwater Fishery Biology (2 ${ }^{\text {nd }}$ Edn.). William C. Brown Co., Dubuque, Iowa. 421p.

Lupatsch, I., Kissil, G.W.M., Sklan, D., 2001. Optimization of feeding regimes for European seabass Dicentrarchus labrax: a factorial approach. Aquaculture. 202, 289-302.

Metailler, R., Aldrin, J.F., Messager, J.L., Mevel, G., Stephan, G., 1981. Feeding of European sea bass Dicentrarchus labrax: role of protein level and energy source. J. World Maricult. Soc. 12, 117-118.

Moretti, A., Pedini Fernandez-Criado, M., Cittolin, G., Guidastri, R., 1999. Manual on hatchery production of seabass and gilthead seabream. Vol. 1. FAO Rome, Italy. $194 \mathrm{p}$.

Mylonas, C.C., Anezaki, L., Divanach, P., Zanuy, S., Piferrer, F., Ron, B. Peduel, A., Ben Atia, I., Gorshkov, S., Tandler, A., 2003. Influence of rearing temperature at two periods during early life on growth and sex differentiation of two strains of European sea bass. Fish Physiol. Biochem. 28, 167-168.

Nascimento, I.A., Bray, W.A., Leung-Trujillo, J.R., Lawrence, A.L., 1991. Reproduction of ablated and unablated Penaeus schmitti in captivity using diets consisting of fresh-frozen natural and dried formulated feeds. Aquaculture. 99, 387-398.

NRC, 1993. Nutrient Requirement of Fish. Committee on Animal Nutrition. Board on Agriculture, National Research Council. National Academy Press, Washington, D.C., USA.

Pantha, B., 1982. The use of soybean in practical feeds for Tilapia niloticus. M.Sc. Thesis. University of Stirling.

Parpoura, A.C.R., Alexis, M.N., 2001. Effects of different dietary oils in sea bass (Dicentrarchus labrax L.) nutrition. Aquacult. Int. 9, 463-476.

Pawson, M.G., Pickett, G.D., 1996. The annual pattern of condition and maturity in bass, Dicentrarchus labrax, in waters around England and Wales. J. Marine Biol. Assoc. $76,107-125$. 
Pieper, A., Pfeffer, E., 1979. Carbohydrates as possible sources of dietary energy for rainbow trout Salmo gairdneri, Richardson. In: Finfish Nutrition and Fishfeed Technology (Eds.: Halver, J.E., Tiews, K.). Vol. I. Heenemann, Berlin. pp.209-219.

Roberts, R.J., 2001. Fish Pathology. $3^{\text {rd }}$ Edn. Elsevier Health Sciences, Philadelphia.

Roche, H., Brichon, G., Pérés, G., 1982a. Influence de la composition du regime alimentaire sur la teneur en lipides et leur nature dans diffkrents tissus du loup (Dicentrurchus lubrus). Rapport CNEXO, Contrat. no. 8 $1 / 2485$.

Roche, H., Jouanneteau, J., Pérés, G., 1982b. Les lipides tissulaires du loup d'elevage. Dicentrurchus lubrux. Comparaison and differentes saisons. CIESM, Cannes, 7p.

Selman, K., Wallace, R.A., 1989. Cellular aspects of oocyte growth in teleosts. Zool. Sci. 6, 211-231.

Seung-Cheol, J.I., Osamu, T., Gwan-Sik, J., Si-Woo, L., Katsuya, I., Manabu, S., Kenji, T., 2007. Dietary medicinal herbs improve growth and some non-specific immunity of red sea bream Pagrus major. Fish. Sci. 73, 63-69.

Shapawi, R., Mustafa, S., Ng, W.K., 2011. A comparison of the growth performance and body composition of humpback grouper (Cromileptes altivelis) fed on farm made feeds, commercial feeds or trash fish. J. Fish. Aquat. Sci. 6, 523-534.

Sim, S.Y., Rimmer, M.A., Toledo, J.D., Sugama, K., Rumengan, I., Williams K.C., Phillips, M.J., 2005. A Practical Guide to Feeds and Feed Management for Cultured Groupers. NACA, Bangkok, Thailand. 18p.

Spyridakis, P., Metailler, R., Gabaudan, J., 1986. Proteine et amidon dans l'alimentation du juvenile de bar ou loup (Dicentrarchus labrax). ICES, C.M. 1986/F: 30, 11p.

Starch, V. Stahlin, W., Juario, J.V., 1983. Effect of different diets on the ultrastructure of hepatocytes of Chunos chunos fry: on electron microscopic and morphometric analysis. Mar. Biol. 74, 101-104.

Takeuchi, M., Ishii, S., Ogino, T., 1981. Effect of dietary vitamin $\mathrm{E}$ on growth, vitamin $\mathrm{E}$ distribution, and mortalities of the fertilized eggs and fry in Ayu, Plecoglossus altivelis. Bull. Tokai Reg. Fish Lab. 104, 111-122.

Teshima, S., Kanazawa, A., 1983. Variation in lipid composition during the ovarian maturation of the prawn. Bull. Jap. Soc. Scient. Fishery. 49, 957-962.

Tibaldi, E., Tulli, F., Ballestrazzi, R., Lanari, D., 1991. Effect of dietary protein/metabolizable energy ratio and body size on the performance of juvenile seabass. Zootec. Nutr. Anim. 17, 313-320.

Tseng, W.Y., Chan, K.L., 1982. The reproductive biology of the rabbit fish in Hong Kong. J. World Maricul. Soc. 13, 313-321.

Venkataramani, V.K., Ramanathan, N., Venkataramanujam, K., 1995. Breeding biology of a carangid fish Selaroides leptolepis cuv (Perciformes) along tuticorin, southeast coast of India. Indian J. Marine Sci. 24(4), 207-210.

Watanabe, T., Arakawa, T., Kitajima, C., Fujita, S., 1984. Effect of nutritional quality of broodstock diet on reproduction of red seabream. Bull. Jap. Soc. Scient. Fisheries. 50(3), 495-501.

Watanabe, T., 1988. Fish Nutrition and Mariculture. The General Aquaculture Course. Kanagawa International Fisheries Training Center, JICA, Kanagawa Prefecture, Kanagawa, Japan.

West, G., 1990. Methods of assessing ovarian development in fishes: a review. Aust. J. Mar. Freshwater Res. 41, 199. 222.

Wootton, R.J., 1990. Ecology of Teleost Fishes. Chapman and Hall, New York, USA. 404p.

\section{How to cite this article:}

Maklad, E. H., Mehrim, A. I., Mohamed, Z.A., 2016. Nutritional-reproductive efficiency relationship of European Sea bass, Dicentrarchus labrax (Linnaeus, 1758) brood stock: Condition factor, organs indices, anatomical and histological characteristics. Int. J. Curr. Res. Biosci. Plant Biol. 3(9), 27-39. doi: http://dx.doi.org/10.20546/ijcrbp.2016.309.004 